\title{
Emerging Diseases as A Challenge for Epidemiological Transition in This Global Village
}

\author{
Kazhal Mobaraki and Jamal Ahmadzadeh* \\ Epidemiologist, Social Determinants of Health Research Center, Urmia University of Medical Sciences, Urmia, Iran
}

*Corresponding author: Jamal Ahmadzadeh, Epidemiologist in Social Determinants of Health Research Center, Urmia University of Medical Sciences, Resalat Street, Urmia, Iran

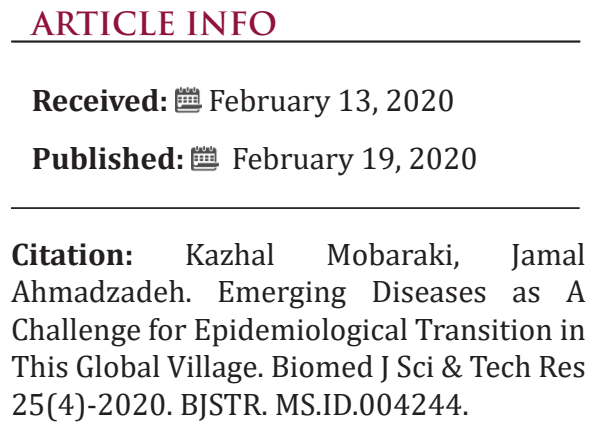

This Global Village. Biomed J Sci \& Tech Res

\begin{abstract}
This commentary provides a quick overview to 2019 novel coronavirus (COVID-19) and other emerging viruses in recent decades. All the evidence related to emerging infections suggests that we are faced with unknown threats and challenges in the epidemiological and heath transition. The coronaviruses already identified such as severe acute respiratory syndrome coronavirus (SARS-COV), Middle East respiratory syndrome coronavirus (MERS-COV), and nowadays COVID-19, may only be the tips of the icebergs, and probably more novel and severe emerging infections might be revealed in the near future in the humans' communities.
\end{abstract}

Keyword: Emerging Diseases; 2019 Novel Coronavirus (COVID-19); Epidemiological Transition

\section{Commentary}

The epidemiological and heath transitions (shifting from infectious diseases to non-communicable diseases) in recent decades had been created false optimism about getting rid of infectious diseases. Previously, everyone thought that the epidemiological transition was a one-way process which begins with a decrease in communicable diseases as a cause of deaths and ends with an increase in non-communicable diseases. For this reason, in the most developed and developing countries noncommunicable diseases such as cardiovascular disease, motor vehicle accidents, cancers, etc. have been considered as the priority for the prevention and allocation of health funds. It is the sad fact that in the past few decades, new emerging diseases have emerged and spread in different geographical areas in this global village. Among the pathogenic infectious agents, viruses are most transformed to cause emerging diseases [1-4].
The global Indicators related to the most prominent of these viruses in recent decades which they caused the rapid outbreak, epidemics, and pandemics in the human populations has been summarized in (Table 1). On 31 December 2019, a cluster of asymptomatic pneumonia cases from Wuhan City (It is the largest city in Hubei province with a population of over 11 million in central China), has been reported to world health organization (WHO). The concern of Chinese authorities and global experts raised on 7 January, when the Chinese authorities after a complex epidemiologic investigation confirmed that they had identified a new coronavirus that did not match with other known coronaviruses such as severe acute respiratory syndrome coronavirus (SARS-COV) and Middle East respiratory syndrome coronavirus (MERS-COV). The WHO officially named the 2019 novel coronavirus as COVID-19 on 11 February 2020 [5-8].

Table 1: The global Indicators related to the most prominent emerging viruses in recent decades.

\begin{tabular}{|c|c|c|c|c|}
\hline Virus name & $\begin{array}{c}\text { Severe Acute Respiratory } \\
\text { Syndrome Coronavirus (SARS- } \\
\text { CoV) [1,2]. }\end{array}$ & $\begin{array}{c}\text { Ebola virus disease (EVD) } \\
{[\mathbf{2 , 3}] .}\end{array}$ & $\begin{array}{c}\text { Middle East respiratory } \\
\text { syndrome coronavirus } \\
\text { (MERS-CoV) [2,4-9]. }\end{array}$ & $\begin{array}{c}\text { 2019 novel } \\
\text { coronavirus } \\
\text { (CoVID-19) [2,10,11]. }\end{array}$ \\
\hline Epi center & China & $\begin{array}{c}\text { West Africa (Guinea and } \\
\text { Sierra Leone and Liberia) }\end{array}$ & Saudi Arabia & China \\
\hline Epidemic time period & November 2002 until April 2004 & $2014-2016$ & $\begin{array}{c}\text { September 2012 until } \\
\text { December 2019 }\end{array}$ & $\begin{array}{c}\text { December 2019 until } \\
\text { February 2020 }\end{array}$ \\
\hline
\end{tabular}




\begin{tabular}{|c|c|c|c|}
\hline Confirmed cases & 8098 & 3429 & 45208 \\
\hline Deaths & 774 & 2251 & 1118 \\
\hline Case fatality rates (\%) & 9.6 & 65.64 & 2494 \\
\hline Countries affected & 26 & $<5$ & 28 \\
\hline $\begin{array}{c}\text { The basic } \\
\text { reproductive rate }\left(\mathrm{R}_{0}\right)\end{array}$ & $2-5$ & 2.3 & $<1$ \\
\hline
\end{tabular}

WHO declared some recommendations for the general public to protect themselves as follows:

a) Frequently washing hands by using water and soap or alcohol-based hand rub.

b) Avoiding close contact with anyone with cold and flu-like symptoms.

c) Covering nose and mouth when coughing and sneezing with a tissue or flexed elbow.

d) Thoroughly cooking raw meat, eggs, raw milk and etc and avoid unprotected contact with sick people (including touching one's eyes, nose or mouth), live wild animals, farm animals, and surfaces in contact with animals.

e) Seeking medical care and share previous travel history with the health care worker if someone had a fever, cough and difficulty breathing.

f) Avoiding travel if someone had a fever and cough [9-12].

The clinical presentation of the confirmed patients with COVID-19 commonly is fever, dry cough, and shortness of breath, and most patients (80\%) will experience mild illness. The basic the reproductive rate of 2019-nCoV has been reported 4 fold more rather than to similar coronaviruses such as SARS-CoV. Current known evidence for COVID-19 suggests that we are now faced with the most virulent coronavirus and epidemic that the world has ever seen. In our previous studies, we have repeatedly warned the global experts that the coronaviruses are fatal and the global burden of premature mortality due to them are increasing in this global village [6,7]. Although our knowledge about coronavirus is rising, some gaps still exist. In the current situation, we hope that that the global community, especially government officials and Health system senior executives in this global village have serious attention to released recommendations and warning in the published literature about emerging infections. In fact, now and in the near future, they should be alert and prepare for responding to the emergence of biological threats such as COVID-19, MERS COV and etc. Here, the authors declare to the senior manager of WHO that the coronaviruses already identified may only be the tip of the iceberg, and probably more novel and severe emerging infections might be revealed in the near future in the humans' communities.

\section{Conflict of Interest}

None declared

\section{Funding}

This research received no specific grant from any funding agency in the public, commercial, or not-for-profit sectors.

\section{References}

1. World Health Organization. Emergencies preparedness, responseSevere Acute Respiratory Syndrome (SARS).

2. Chen J (2020) Pathogenicity and Transmissibility of 2019-nCoV-A Quick Overview and Comparison with Other Emerging Viruses. Microbes Infect.

3. World Health Organization. Emergencies preparedness, response-Ebola virus disease-Democratic Republic of the Congo.

4. World Health Organization. Middle East respiratory syndrome coronavirus (MERS-CoV).

5. Salamatbakhsh M, Mobaraki K, Ahmadzadeh J (2020) Syndromic Surveillance System for MERS-CoV as New Early Warning and Identification Approach. Risk Manag Healthc Policy 13: 93-95.

6. Salamatbakhsh M, Mobaraki K, Sadeghimohammadi S, Ahmadzadeh J (2019) The global burden of premature mortality due to the Middle East respiratory syndrome (MERS) using standard expected years of life lost, 2012 to 2019. BMC public health 19(1): 1523.

7. Mobaraki K, Ahmadzadeh J (2019) Current epidemiological status of Middle East respiratory syndrome coronavirus in the world from 1.1. 2017 to 17.1. 2018: a cross-sectional study. BMC Infect Dis 19(1): 351.

8. Ahmadzadeh J, Mobaraki K (2019) Epidemiological status of the Middle East respiratory syndrome coronavirus in 2019: an update from January 1 to March 31, 2019. Int J Gen Med 12: 305.

9. Mobaraki K, Salamatbakhsh M, Ahmadzadeh J (2019) Standard Expected Years of Life Lost as a Neglected Index for Calculating the Burden of Premature Mortality due to Middle East Respiratory Syndrome. Health Secur 17(5): 407-409.

10. World Health Organization. Novel coronavirus (2019-nCoV).

11. COVID-19 CORONAVIRUS OUTBREAK. 
ISSN: 2574-1241

DOI: 10.26717/BJSTR.2020.25.004244

Jamal Ahmadzadeh. Biomed J Sci \& Tech Res

(c) (P) This work is licensed under Creative

Submission Link: https://biomedres.us/submit-manuscript.php

$\begin{array}{ll}\text { BIOMEDICAL } & \text { Assets of Publishing with us } \\ \text { RESEARCHES } & \text { - Global archiving of articles } \\ \text { - Immediate, unrestricted online access }\end{array}$

